\title{
Serum immunoreactive prolyl hydroxylase in inflammatory rheumatic diseases
}

\author{
EEVA-RIITTA KUUTTI-SAVOLAINEN ${ }^{1}$, KARI I. KIVIRIKKO ${ }^{1}$, AND \\ OSSI LAITINEN ${ }^{2} 3$
}

From the ${ }^{1}$ Department of Medical Biochemistry, University of Oulu, Oulu, Finland, the ${ }^{2}$ Third Department of Medicine, University of Helsinki, Helsinki, Finland, and the ${ }^{3}$ Department of Rheumatology, Karolinska Hospital, Stockholm, Sweden

SUMMARY Serum immunoreactive prolyl hydroxylase protein (S-IRPH) was measured in 56 patients with inflammatory rheumatic diseases, and the values were compared with those in 32 control subjects. S-IRPH was above the $95 \%$ confidence limit of the controls in about $70 \%$ of the patients with active systemic lupus erythematosus, rheumatoid arthritis, scleroderma, Reiter's syndrome, Sjögren's syndrome, polyarteritis nodosa, or polymyositis. Raised values were observed in about half of the patients with an erythrocyte sedimentation rate (ESR) of 21-50 and in about $90 \%$ of those with ESR of over 50 , whereas only about $10 \%$ of the patients with an inactive disease had an S-IRPH concentration exceeding this limit. Only 1 out of 8 patients with active ankylosing spondylitis had a raised S-IRPH value. The results support previous data indicating that significant changes in collagen metabolism occur in active connective tissue diseases. Assays of S-IRPH might be of some value in assessing the activity of these diseases and in monitoring the treatment provided.

A number of observations indicate that definite changes in collagen metabolism occur in connective tissue diseases. Studies on collagen solubility, ${ }^{1-5}$ the rate of incorporation of radioactive proline into skin collagen in vitro, ${ }^{4-8}$ and the pattern of collagen cross-links ${ }^{9}$ are all consistent with an increased rate of formation of this protein in some patients with connective tissue diseases. The activities of two intracellular enzymes of collagen biosynthesis, prolyl hydroxylase $\mathrm{e}^{10-12}$ and galactosylhydroxylysyl glucosyltransferase, ${ }^{13}$ are similarly elevated in the skin in some of these diseases, and an increased activity of the former enzyme has been reported in rheumatoid synovial tissue. ${ }^{14}$ The rate of collagen degradation is likewise altered. An increased collagenase activity is found in the synovial tissue $^{15-17}$ and synovial fluid ${ }^{1819}$ of patients with rheumatoid arthritis, while the urinary excretion of hydroxyproline, which reflects the turnover of collagen in a number of tissues, is elevated in patients with most connective tissue diseases (reviews $\left.{ }^{20}{ }^{21}\right)$.

Accepted for publication 1 June 1979

Correspondence to Dr Eeva-Riitta Kuutti-Savolainen, Department of Medical Biochemistry, University of Oulu, Kajaanintie 52 A, SF-90220 Oulu 22, Finland.
The biosynthesis of collagen involves many unique post-translational enzyme reactions, and these have been the subject of intensive investigation during recent years (reviews $^{22-24}$ ). The hydroxylation of prolyl residues has an important role among these reactions, as the newly-synthesised polypeptide chains do not form triple-helical, functional molecules if the chains are deficient in hydroxyproline (see above reviews). Measurements of prolyl hydroxylase activity in a number of experimental and clinical states have indicated that this enzyme activity is usually increased in conditions associated with an enhanced rate of collagen formation (review ${ }^{25}$ ). Prolyl hydroxylase activity is also found in human serum, 2627 though the activity is quite low and has failed to be detected in some instances. ${ }^{28}$ More recently the presence of immunoreactive prolyl hydroxylase protein (S-IRPH) has been demonstrated in human serum, ${ }^{29}$ most of this protein corresponding in size to the inactive monomers of the active enzyme tetramer. ${ }^{30}$ So far increases in S-IRPH have been found particularly in patients with diseases associated with an increased prolyl hydroxylase activity in the liver, and it has been suggested that assays of this serum protein may give useful information on actual hepatic collagen synthesis. ${ }^{31} 37$ 
S-IRPH has also been measured in a number of patients with various dermatological diseases limited to the skin and has been found to be within the normal limits in essentially all of them, even though many of the patients had increased prolyl hydroxylase activity in the skin lesions. ${ }^{32}$ By contrast a group of 7 patients having active systemic connective tissue diseases with skin affections, including systemic lupus erythematosus, scleroderma, and dermatomyositis, showed elevated S-IRPH in 4 cases, though the enzyme activity in the skin was elevated in only 1.32 These observations suggested a study on changes in S-IRPH using a larger series of patients with connective tissue diseases.

\section{Patients and methods}

\section{PATIENTS}

Sera from 56 patients with the following rheumatic diseases were examined: 20 with systemic lupus erythematosus (SLE), 16 with rheumatoid arthritis (RA), 10 with ankylosing spondylitis (AS), 5 with scleroderma (SCL), 2 with Reiter's syndrome, 1 with Sjögren's syndrome, 1 with polyarteritis nodosa, and 1 with polymyositis. The distribution of the patients by age and sex is given in Table 1 . The patients with SLE had signs of multiple systemic involvement of the disease, positive tests for the LE phenomenon, and antinuclear antibodies, and they all fulfilled the preliminary criteria of the ARA for a diagnosis of SLE. ${ }^{33}$ RA similarly fulfilled the ARA criteria, ${ }^{34}$ and AS the diagnostic criteria for this disease. ${ }^{35}$ The SCL patients displayed characteristic clinical symptoms, and the diagnosis was substantiated by positive skin biopsies and radiological evidence of oesophageal and/or skeletal involvement. The patients with Reiter's syndrome, Sjögren's syndrome, polyarteritis nodosa, and polymyositis were all typical cases with an active disease. The patients were diagnosed at the Department of Rheumatology, Karolinska Hospital,
Stockholm, and the series included patients with greatly varying disease activities, mostly receiving some antirheumatic medication. The S-IRPH values were compared with those in 32 apparently healthy controls, as used previously. ${ }^{32}$ The control sera were stored frozen at $-20^{\circ} \mathrm{C}$ and reassayed together with the sera from the patients.

\section{MEASUREMENT OF SERUM IMMUNOREACTIVE \\ PROLYL HYDROXYLASE}

The concentration of S-IRPH was measured by a direct radioimmunoassay based on the displacement of radioactively labelled prolyl hydroxylase from its antibody by nonlabelled enzyme and the subsequent precipitation of the enzyme-antibody complex by a cellulose-bound second antibody. ${ }^{29}$ The assay measures both the active enzyme tetramers and the inactive monomers, the degree of displacement of the labelled enzyme being similar regardless of whether the enzyme is in the tetramer or monomer form. ${ }^{29}$ Pure human prolyl hydroxylase ${ }^{36}$ was used to produce the antiserum and to prepare the labelled enzyme, and was also used as the enzyme standard. The sera were stored frozen at $-20^{\circ} \mathrm{C}$, with no thawing, for up to 4 years until assayed. It has previously been reported that sera can be stored at $-20^{\circ} \mathrm{C}$ for at least 2 years with no loss in S-IRPH, ${ }^{37}$ and additional control experiments on 10 sera which had been analysed for S-IRPH and then stored at $-20^{\circ} \mathrm{C}$ for 4 years indicated no loss in this protein with either high or low original concentrations.

\section{Results}

The mean S-IRPH concentration was significantly raised in the patients with SLE, RA, AS, and SCL, and individual values in the patients with other diseases included in these series were also high, with the exception of 1 case of Reiter's syndrome (Table 1). As the disease activities varied greatly

Table 1 Serum immunoreactive prolyl hydroxylase $(S-I R P H)$ in controls and in patients with inflammatory rheumatic diseases

\begin{tabular}{|c|c|c|c|c|c|c|}
\hline \multirow[t]{2}{*}{ Group } & \multirow[t]{2}{*}{$n$} & \multicolumn{2}{|l|}{ Sex } & \multirow{2}{*}{$\begin{array}{l}\text { Age* } \\
\text { (years) }\end{array}$} & \multirow{2}{*}{$\begin{array}{l}S-I R P H^{*} \\
(m g / l)\end{array}$} & \multirow[t]{2}{*}{$P \dagger$} \\
\hline & & Males & Females & & & \\
\hline
\end{tabular}

*Mean $\pm S D$; in Reiter's syndrome individual values.

tStatistical significance of the difference in S-IRPH when compared with the controls (Student's $t$ test); ND=not determinod. 
between individual patients, the series was divided into 3 subgroups on the basis of the erythrocyte sedimentation rate (ESR): subgroup 0, consisting of patients with inactive disease, ESR less than 21 (12 cases, ESR $9 \pm 6$, mean \pm SD); subgroup 1, active disease, ESR 21-50 (22 cases, ESR $35 \pm 7$ ); and subgroup 2, very active disease, ESR more than 50 ( 22 cases, ESR $85 \pm 28$ ). The other laboratory data and clinical symptoms were consistent with this division.

In the patients with SLE and RA about half of the S-IRPH values in subgroup 1 (4 out of 10 with SLE and 2 out of 4 with RA) and $80-90 \%$ in subgroup 2 (5 out of 6 with SLE and 7 out of 8 with RA) were above the normal upper limit $1.58 \mathrm{mg} / \mathrm{l}$, defined as the mean +2 SD of the controls (Fig. 1), whereas none of the 8 values in cases of inactive SLE and RA was above the limit. All 3 patients with very active SCL and all with very active Reiter's syndrome, polyarteritis nodosa, or polymyositis likewise had S-IRPH values exceeding the normal upper limit, whereas the patient with Reiter's syndrome belonging to subgroup 1 had a value below the limit. One of the 2 values for inactive SCL was elevated. An extremely high value was found in the 1 active case of Sjögren's syndrome, which had an ESR of 41 on the day of the study, although much higher values were frequently recorded. The patients with AS differed clearly from the others in that only 1 out of 6 S-IRPH values in subgroup 1 and neither of the 2 in subgroup 2 exceeded the normal upper limit (Fig. 1), even though the mean ESR values for AS cases in subgroups 1 and 2 were essentially identical with those in the corresponding subgroups of the whole patient series.
There was a highly significant correlation between S-IRPH and ESR in SLE $(r=0.687, P<0.001)$, a weak correlation in $\mathrm{RA}(\mathrm{r}=0.559, \mathrm{P}<0.05)$ and a significant correlation in the whole patient series excluding AS $(r=0.400, P<0.01)$, whereas no correlation was found in AS $(r=0 \cdot 230)$.

\section{Discussion}

The results indicate that S-IRPH is above the normal upper limit in about $70 \%$ of all patients with the active diseases studied here, excluding AS, but is below this limit in about $90 \%$ of those with an inactive disease. High values were found in about half of the cases in subgroup 1 (ESR 21-50) and in about $90 \%$ in subgroup 2 (ESR $>50$ ). These findings agree with those reported previously in patients having active systemic connective tissue diseases with skin manifestations (see above), in that out of these 7 patients, all of whom had an ESR of 21-50, 4 had an elevated S-IRPH. These data thus provide a further parameter pointing to distinct changes in collagen metabolism in connective tissue diseases.

High S-IRPH concentrations have previously been reported in patients with increased prolyl hydroxylase activity in the liver, including cancer with liver metastases, ${ }^{31} 27$ and in a few patients having malignant diseases without liver involvement, whereas essentially all the patients with dermatological diseases having an increased prolyl hydroxylase activity in the skin lesions had normal S-IRPH concentrations. ${ }^{32}$ In liver diseases a significant correlation was found between prolyl hydroxylase activity in the hepatic biopsy specimens and S-IRPH concentration. ${ }^{37}$ It thus seems that an elevated prolyl hydroxylase activity in the liver alone can be

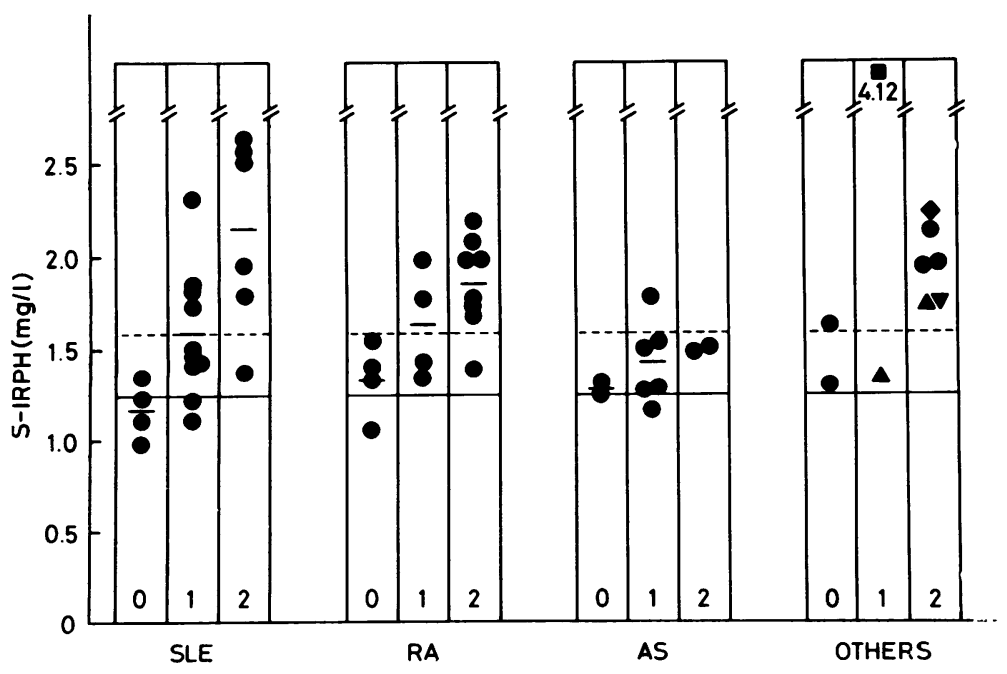

Fig. $1 S$-IRPH in patients with systemic lupus erythematosus $(S L E)$, rheumatoid arthritis $(R A)$, ankylosing spondylitis $(A S)$, scleroderma ( $\bullet$ in 'others'), Reiter's syndrome ( $\Delta$ ), Sjögren's syndrome ( $\square)$, in polyarteritis nodosa $(\diamond)$, and polymyositis $(\nabla)$. The horizontal dashed line indicates the limit of the mean + $2 S D$ of the controls, the solid line the mean of the controls, and the short solid lines the means of the subgroups $0(E S R<21)$, 1 (ESR 21-50), and $2(E S R>50)$. 
associated with increased S-IRPH whereas an increased activity in other instances may not have an appreciable effect on the S-IRPH concentration unless the change is quite marked or is present in a number of connective tissues. In this connection it is of interest that, although the mean S-IRPH was elevated in AS, only 1 out of 8 patients with an active or very active disease had a value exceeding the normal upper limit.

The present data on S-IRPH differ from those previously reported for serum prolyl hydroxylase activity in that increases in the latter were found in certain diseases affecting the liver, especially hepatocellular carcinoma, whereas a group of 32 patients with various connective tissue diseases included only 1 value in a case of scleroderma which was above the mean +2 SD of controls. ${ }^{26}$ Several reasons can be found for this difference. Firstly, the assays of serum prolyl hydroxylase activity measure only the active enzyme tetramers, whereas the radioimmunoassay used here also measures the inactive enzyme protein, more than $90 \%$ of S-IRPH being the inactive form. ${ }^{30}$ Secondly, the assay of the serum enzyme activity is relatively insensitive, and the normal values lie just within the limits of detection, resulting in an artificially high scatter; and thirdly, the serum also contains inhibitors of prolyl hydroxylase activity. ${ }^{38}$ An additional problem in assays of serum prolyl hydroxylase activity is the rapid inactivation of this enzyme, ${ }^{26}$ whereas S-IRPH is very stable. ${ }^{37}$

The correlation between S-IRPH and ESR in the whole series of patients apart from those with AS, and the distribution of raised S-IRPH values between the subgroups 0,1 , and 2 indicate that the elevation of S-IRPH correlates with the disease activity. The ESR is not an optimal indicator of disease activity, however, and hence it is not surprising to find some disagreement between S-IRPH and ESR in a number of individual values. Assays of S-IRPH can be carried out quite easily provided that pure human prolyl hydroxylase and its antiserum are available, and they require less than $50 \mu \mathrm{l}$ of serum. It would thus seem that assays of S-IRPH could be of some value in assessing the activity of connective tissue diseases and in monitoring their treatment. More extensive studies are required, however, to elucidate the possible usefulness of S-IRPH determinations for these purposes.

The authors are grateful to Professor Börje Olhagen and Docent Ragnhil Gullberg, of the Department of Rheumatology, Karolinska Hospital, Stockholm, for permission to obtain the sera, and Mrs Ritva Pihkakoski, Mrs Laina Göransson, and Mrs Irene Kronmyr for their expert technical assistance. This work was supported in part by grants from the Medical Research Council of the Academy of Finland.

\section{References}

1 Korting G W, Holzmann H, Kühn K. Biochemische Bindegewebsanalysen bei progressiver Sklerodermie. Klin Wochenschr 1964; 42: 247-248.

2 Harris E D Jr, Sjoerdsma A. Collagen profile in various clinical conditions. Lancet 1966; 2: 707-711.

3 Laitinen O, Uitto J, Hannuksela M, Mustakallio K K. Increased soluble collagen content of affected and normallooking skin in dermatomyositis, lupus erythematosus and scleroderma. Ann Med Exp Biol Fenn 1966; 44: 507509.

4 Laitinen O, Uitto J, Hannuksela M, Mustakallio K K. Solubility and turnover of collagen in collagen diseases. Ann Clin Res 1969; 1: 64-73.

5 Uitto J, Øhlenschläger K, Lorenzen I. Solubility of skin collagen in normal human subjects and in patients with generalised scleroderma. Clin Chim Acta 1971; 31: 13-18.

6 Keiser H R, Sjoerdsma A. Direct measurement of the rate of collagen synthesis in skin. Clin Chim Acta 1969; 23: 341-346.

7 Uitto J, Helin P, Rasmussen O, Lorenzen I. Skin collagen in patients with scleroderma: Biosynthesis and maturation in vitro, and the effect of D-penicillamine. Ann Clin Res 1970; 2: 228-234.

8 Uitto J, Helin G, Helin P, Lorenzen I. Connective tissue in scleroderma. A biochemical study on the correlation of fractionated glycosaminoglycans and collagen in human skin. Acta Derm Venerol (Stockh) 1971; 51 : 401406.

9 Herbert C M, Lindberg K A, Jayson M I V, Bailey A J. Biosynthesis and maturation of skin collagen in scleroderma and the effect of D-penicillamine. Lancet 1974; 1: $187-192$.

10 Uitto J. Halme J, Hannuksela M, Peltokallio P, Kivirikko K I. Protocollagen proline hydroxylase activity in the skin of normal human subjects and of patients with scleroderma. Scand J Clin Lab Invest 1969; 23: 241-247.

11 Uitto J, Hannuksela M, Rasmussen O G. Protocollagen proline hydroxylase activity in scleroderma and other connective tissue diseases. Ann Clin Res 1970; 2: 235 239.

12 Keiser H R, Stein H D, Sjoerdsma A. Increased protocollagen proline hydroxylase activity in sclerodermatous skin. Arch Dermatol 1971; 104: 57-60.

13 Kuutti-Savolainen E - R, and Kero M. Enzymes of collagen biosynthesis in skin and serum in dermatological diseases. I. Enzymes of the skin. Clin Chim Acta 1979; 96: 43-51.

14 Uitto J, Lindy S, Rokkanen P, Vainio K. Increased protocollagen proline hydroxylase activity in synovial tissue in rheumatoid arthritis. Clin Chim Acta 1970; 30: $741-744$.

15 Evanson J M, Jeffrey J J, Krane S M. Human collagenase: identification and characterisation of an enzyme from rheumatoid synovium in culture. Science 1967; 158: 499-502.

16 Lindy S, Halme J, Turto H, Rokkanen P, Vainio K, Wegelius $O$. Collagenolytic activity in rheumatoid synovial tissue. Clin Chim Acta 1973; 47: 153-157.

17 Werb Z, Mainardi C L, Vater C A, Harris E D Jr. Endogenous activation of latent collagenase by rheumatoid synovial cells. Evidence for a role of plasminogen activator. N Engl J Med 1977; 296: 1017-1023.

18 Harris E D Jr, DiBona D R, Krane S M. Collagenases in human synovial fluid. J Clin Invest 1969; 48: 2104 2113.

19 Peltonen L. Collagenase in synovial fluid. Scand $J$ Rheumatol 1978: 7: 49-54. 
20 Kivirikko K I, Urinary excretion of hydroxyproline in health and disease. Int Rev Connect Tissue Res 1970; 5: $93-163$.

21 Laitinen $O$. Clinical applications of urinary hydroxyproline determination. Acta Med Scand 1974; Suppl. 577: 1-57.

22 Kivirikko K I, Risteli L. Biosynthesis of collagen and its alterations in pathological states. Med Biol 1976; 54: 159-186.

23 Fessler J H, Fessler L I. Biosynthesis of pro-collagen. Ann Rev Biochem 1978; 47: 129-162.

24 Prockop D J, Kivirikko K I, Tuderman L, Guzman N A. The biosynthesis of collagen and its disorders. $N$ Engl $J$ Med 1979; 301 : 13-23; 77-85.

25 Kivirikko K I, Myllylä R. The hydroxylation of prolyl and lysyl residues. In: The Enzymology of Post-translational Modifications of Proteins. Eds. Freedman R B, Hawkins H. London: Academic Press 1979; in press.

26 Stein H D, Keiser H R, Sjoerdsma A. Proline hydroxylase activity in human blood. Lancet, 1970; 1: 106-109.

27 Keiser H R, Vogel C L, Sadikali F. Protocollagen proline hydroxylase in sera of Ugandans with hepatocellular carcinoma. J Nat Cancer Inst 1972; 49: 1251-1255.

28 Takeuchi T, Prockop D J. Protocollagen proline hydroxylase in normal liver and in hepatic fibrosis. Gastroenterology 1969 ; 56: 744-750.

29 Tuderman L, Kuutti E-R, Kivirikko K I. Radio-immunoassay for human and chick prolyl hydroxylase. Eur $J$ Biochem 1975; 60: 399-405.

30 Tuderman L, Kivirikko K I. Immunoreactive prolyl hydroxylase in human skin, serum and synovial fluid: changes in the content and components with age. Eur J Clin Invest 1977; 7: 295-299.

31 Tuderman L, Risteli J, Miettinen T A, Kivirikko K I. Serum immunoreactive prolyl hydroxylase in liver disease. Eur J Clin Invest 1977; 7: 537-541.

32 Kuutti-Savolainen E -R. Enzymes of collagen biosynthesis in skin and serum in dermatological diseases. II. Serum enzymes. Clin Chim Acta 1979; 96: 53-58.

33 Cohen A S, Reynolds W E, Franklin E C, Kulka J P. Ropes M W, Shulman L E, Wallace S L. Preliminary criteria for the classification of systemic lupus erythematosus. Bull Rheum Dis 1971; 21 : 643-648.

34 Ropes M W, Burnett C A, Cobb S. Diagnostic criteria for rheumatoid arthritis. Bull Rheum Dis 1958; 9: 175176.

35 Bennett P H, Wood P H N. (eds). Population studies of the rheumatic diseases. In: Proceedings of the Third International Symposium. Amsterdam: Excerpta Medica, $1968 ; 456$.

36 Kuutti E -R, Tuderman L, Kivirikko K I. Human prolyl hydroxylase. Purification, partial characterisation and prepration of antiserum to the enzyme. Eur $J$ Biochem 1975; 57: 181-188.

37 Kuutti-Savolainen E -R. Risteli J, Miettinen T A, Kiivrikko K I. Collagen biosynthesis enzymes in serum and hepatic tissue in liver disease. I. Prolyl hydroxylase. Eur J Clin Invest 1979; 9: 89-95.

38 Stassen F L H, Cardinale G J, McGee J O'D, Udenfriend S. Prolyl hydroxylase and an immunologically related protein in mammalian tissues. Arch Biochem Biophys 1974; 160: 340-345. 